\title{
Surgically treated Cronkhite-Canada syndrome associated with gastric cancer
}

\author{
Tomohisa Egawa ${ }^{1}$, Tetsuro Kubota ${ }^{1}$, Yoshihide Otani ${ }^{1}$, Naoto Kurihara ${ }^{1}$, Sadanori Abe ${ }^{1}$, Masaru Kimata ${ }^{1}$, \\ Joh Tokuyama ${ }^{1}$, Norihito Wada ${ }^{1}$, Kazuhiro Suganuma ${ }^{1}$, Yuusuke Kuwano ${ }^{1}$, Koichiro Kumai ${ }^{2}$, \\ Yoshinori Sugino ${ }^{3}$, Makio Mukai ${ }^{4}$, and Masaki Kitajima ${ }^{1,2}$ \\ ${ }^{1}$ Department of Surgery, School of Medicine, Keio University, 35 Shinanomachi, Shinjuku-ku, Tokyo 160-8582, Japan \\ ${ }^{2}$ Center for Diagnostic and Therapeutic Endoscopy, School of Medicine, Keio University, Tokyo, Japan \\ ${ }^{3}$ Department of Radiology, School of Medicine, Keio University, Tokyo, Japan \\ ${ }^{4}$ Division of Surgical Pathology, School of Medicine, Keio University, Tokyo, Japan
}

\begin{abstract}
Cronkhite-Canada syndrome is generally accepted to be a benign disorder, with 374 reported cases to the present. Worldwide, there have been 18 previously reported cases of Cronkhite-Canada syndrome associated with gastric cancer. In this report we describe a case of a 52-year-old man with the clinical features of Cronkhite-Canada syndrome combined with gastric cancer. Although the gastric tumor was located at the antrum of the stomach, we performed a total gastrectomy because of the edematous swelling and high risk of malignancy in the remnant stomach. As Cronkhite-Canada syndrome may be a premalignant condition for gastric cancer, as well as for colorectal cancer, we suggest periodic examination of the stomach, colon, and rectum for patients with CronkhiteCanada syndrome.
\end{abstract}

Key words Cronkhite-Canada syndrome · Gastric cancer

\section{Introduction}

In 1955, Cronkhite and Canada [1] reported two cases of patients that suffered from generalized gastrointestinal polyps associated with pigmentation of the skin, alopecia, and atrophy of the finger nails and toenails. Following this initial description, a number of similar cases have since been reported. Although Cronkhite-Canada syndrome is generally accepted to be a benign disorder, we report a case of this syndrome in a patient in whom gastric carcinoma, combined with multiple gastric polyps, was diagnosed.

Offprint requests to: T. Egawa

Received: July 24, 2000 / Accepted: September 18, 2000

\section{Case report}

A 52-year-old Japanese man noticed watery diarrhea, alopecia, dysgeusia, and nail atrophy (Fig. 1) in October 1998 and visited a hospital. He underwent abdominal computed tomography (CT) scanning and ultrasonography, but no abnormal findings were observed. Because the symptoms persisted, and edema of the extremities also occurred, he visited our hospital, in January 1999, and was admitted in March 1999 for further examination. His family had no history of significant bowel disease. Physical examinations revealed that he had relatively poor nutrition, with loss of scalp hair, atrophy of fingernails and toenails, and edema of the extremities, while other physical examination results were unremarkable. Laboratory tests showed hypoproteinemia (total protein, $4.3 \mathrm{~g} / \mathrm{dl}$; albumin, $2.0 \mathrm{~g} / \mathrm{dl}$ ), and poor nutrition. Serum levels of $\mathrm{Zn}$ and cholinesterase (ChE) were slightly decreased, while levels of liver enzymes and creatinine were all normal. Serum carcinoembryonic antigen level was $5.5 \mathrm{ng} / \mathrm{ml}$ (normal range at our hospital, less than $5.0 \mathrm{ng} / \mathrm{ml}$ ). Radiological examination revealed multiple polyps and a protruding tumor located on the posterior wall of the antrum of the stomach (Fig. 2), while a barium enema also showed multiple polyps, from the transverse colon to the rectum. Gastrofiberscopy and colonofiberscopy confirmed the presence of polyps. While colon polyps are a typical feature of Cronkhite-Canada syndrome and have been shown by histology to be benign, the histological findings of the biopsied specimens from the antrum revealed the protruding tumor to be an adenocarcinoma.

The patient was diagnosed as having CronkhiteCanada syndrome with gastric cancer, and a laparotomy was performed on April 20, 1999. The stomach, small intestine, and colon were edematous; this was probably caused by the hypoproteinemia. Total gastrectomy combined with lymph node dissection (D2) was 


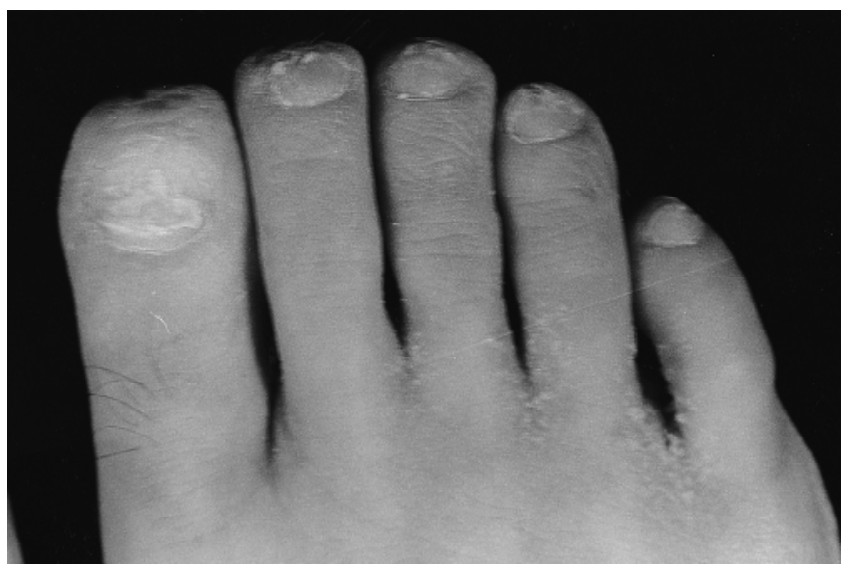

Fig. 1. Photograph of toenails, showing onycodystrophy

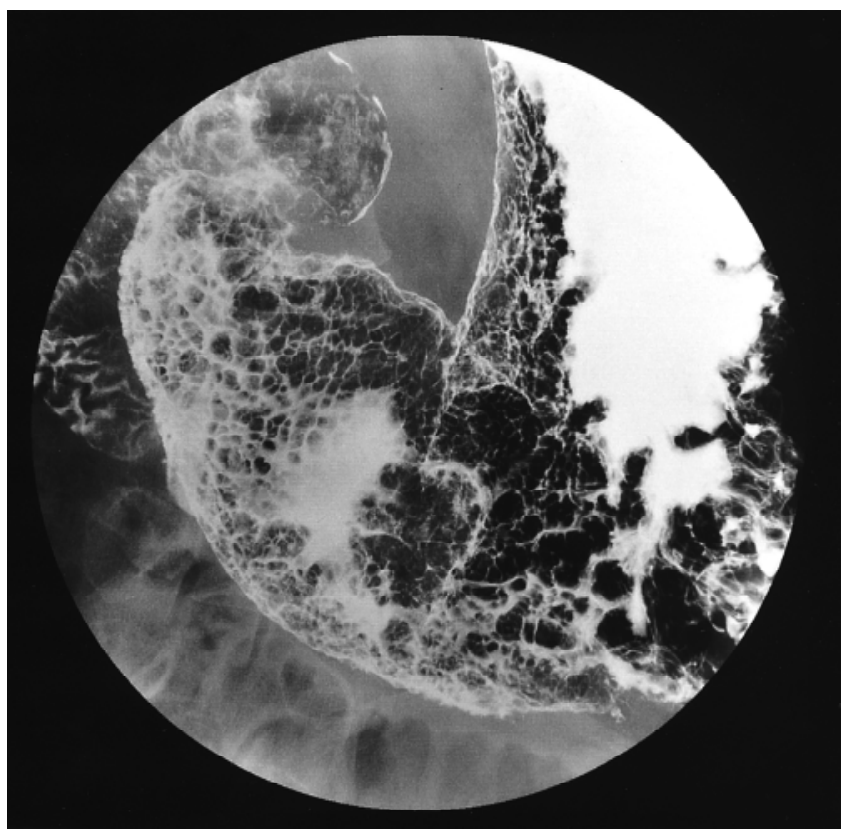

Fig. 2. Radiographic image of the stomach, showing multiple polyps and a protruding tumor located on the posterior wall of the antrum

performed. About $1000 \mathrm{ml}$ of serous bloody fluid was discharged during the operation; however, the cancer invasion was histologically limited to the muscularis propria, with no evidence of lymph node metastasis. The surgical specimen revealed diffuse multiple polyps associated with type 1 tumor (according to the Japanese classification of gastric carcinoma of the Japanese Research Society for Gastric Cancer [2]) located on the posterior wall of the gastric antrum (Fig. 3).

After the operation, the patient had an uneventful course and recovered from the hypoproteinemia, alopecia, and nail atrophy.

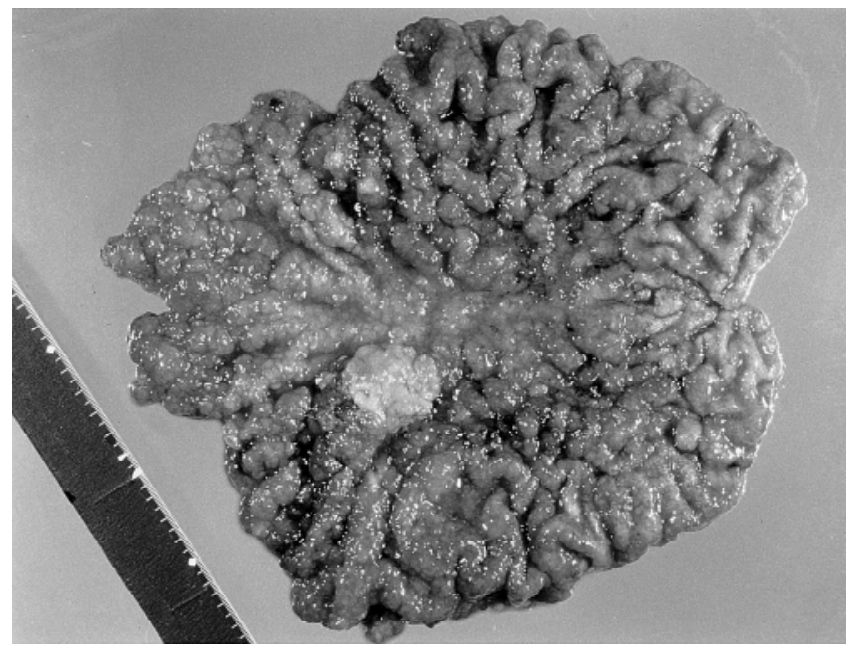

Fig. 3. Gross appearance of the resected specimen

\section{Pathological findings}

Surgical specimens were fixed in $10 \%$ formalin and embedded in paraffin. Sections of the paraffinembedded specimens were stained with hematoxylineosin (H\&E) and showed typical features of Cronkhite-Canada syndrome, including massive submucosal edema, mild infiltration of inflammatory cells, hyperplasia of the foveolar epithelium, and cystic dilatation of the mucosal glands (Fig. 4a,b). Cancer nests, predominantly consisting of poorly differentiated adenocarcinoma cells combined with partly tubular formations of cancer cells, were observed; however, no adenomatous changes were observed around the cancer nests, suggesting that the cancer originated directly from the gastric mucosa. This idea was also validated by Ki-67 (Fig. 5a) and p53 (Fig. 5b) staining, in which only cancer cells were stained with Ki-67 and p53, indicating that only the cancer cells had proliferative activity and that there was mutated p53 protein without intermediate changes between the surrounding mucosa and cancer nests. Although cancer tissue infiltration, up to the muscularis propria, and lymphatic invasion were observed, no lymph node metastases were observed in 28 resected regional lymph nodes. After resection of the jejunal mucosa during the Roux-en-Y anastomosis, H\&E-stained jejunal mucosa specimens showed mild hyperplasia of the foveolar epithelium, mild edema of intestinal tissue, and chronic infiltration of inflammatory cells. However, these changes were slight compared with the changes observed in the gastric mucosa.

\section{Discussion}

Cronkhite-Canada syndrome was first reported in 1955 as generalized gastrointestinal polyposis with ecto- 


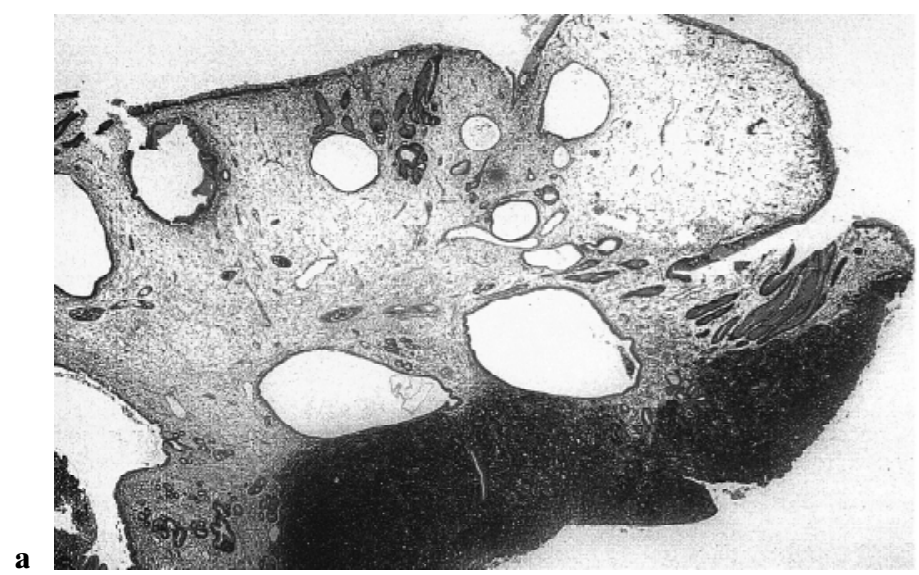

Fig. 4. a Loupe view of the tumor. The border between the cancer and polyps was very clear. b High-power view of $\mathbf{a}$. The gastric specimen showed typical features of CronkhiteCanada syndrome, including massive submucosal edema, mild

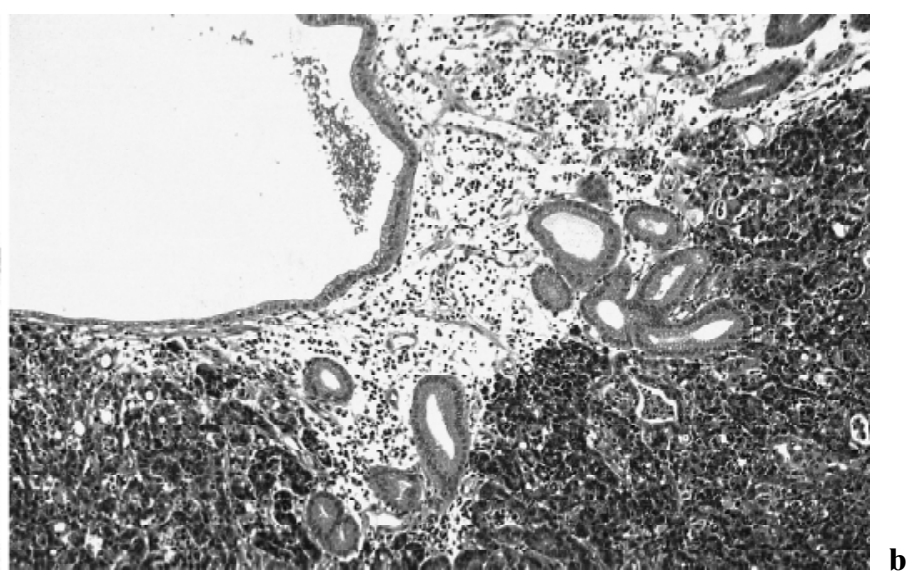

infiltration of inflammatory cells, hyperplasia of the foveolar epithelium, and cystic dilatation of mucosal glands. b H\&E, $\times 40$
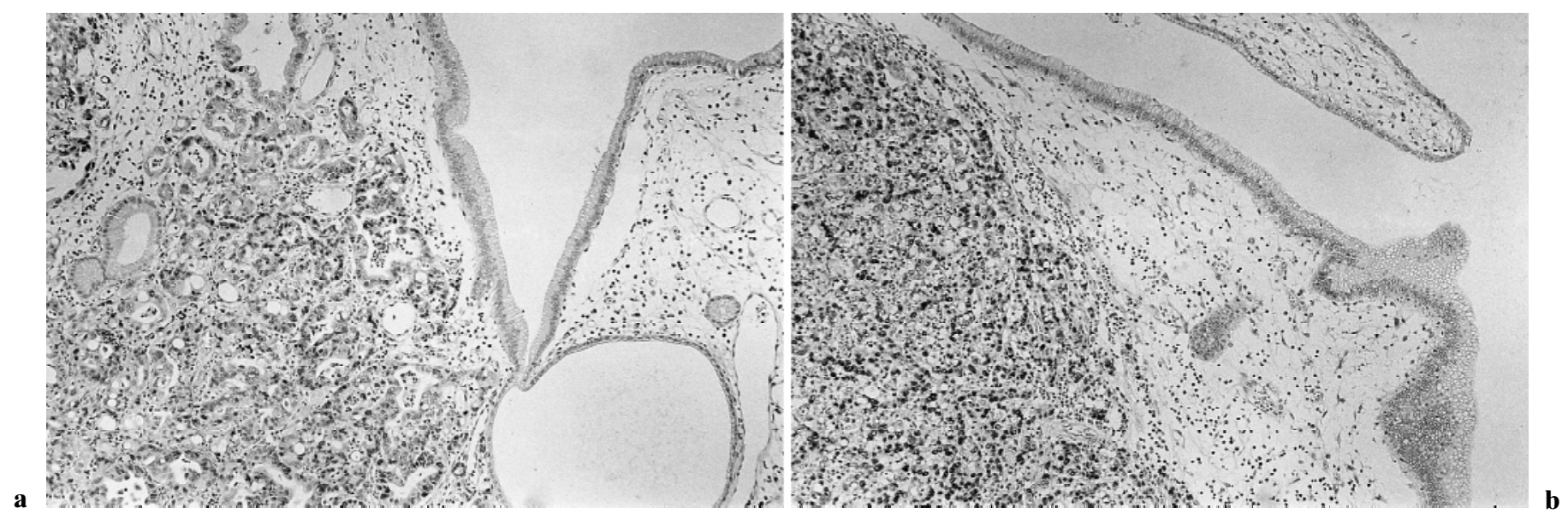

Fig. 5a,b. Only cancer cells were stained with a Ki-67 and b p53. a and b, $\times 40$

dermal changes consisting of alopecia, hyperpigmentation, and onychodystrophy [1]. The major presenting symptom is watery diarrhea, frequently associated with dysgeusia, anorexia, weight loss, and peripheral edema caused by hypoproteinemia [3]. Although polyps are present throughout the gastrointestinal tract in Cronkhite-Canada syndrome, esophageal polyps are very rare, probably because of their squamous cell origin. In their original report, Cronkhite and Canada considered the polyps to be adenomatous. However, recent reports have shown that the polyps contain cystically dilated glands without cellular atypia and resemble juvenile-type polyps, suggesting that the polyps may be non-neoplastic in nature [4]. Malignant transformation of Cronkhite-Canada syndromeassociated polyps is considered extremely rare and coincidental. Of the increasing numbers of reports of this syndrome, those that note an association with carcinoma in the gastrointestinal tract refer to the colon. Up to the end of 1998, 374 cases of this syndrome had been reported in the world literature. Gastric cancer associated with Cronkhite-Canada syndrome was first described by Nakamura et al. [5] in 1979, and the 19 reported cases of Cronkhite-Canada syndrome occurring with gastric cancer (including the present case) are shown in Table 1.

The association rate between Cronkhite-Canada syndrome and gastric cancer is 5.1\% (19/374), with the 19 patients consisting of 15 men and 4 women, ranging in age from 46 to 78 years (mean age, 64.2 years), with all patients originating from Japan. The mortality rate of gastric cancer in Japan has been reported to be approximately 100 per 100000 population for the past 20 years [23]. Although the true incidence of gastric 
Table 1. Reported cases of Cronkhite-Canada syndrome associated with gastric cancer

\begin{tabular}{|c|c|c|c|c|c|c|c|c|}
\hline No. & Author & Year & $\begin{array}{c}\text { Age } \\
\text { (years) }\end{array}$ & Sex & $\begin{array}{l}\text { Depth of } \\
\text { invasion }\end{array}$ & Location & $\begin{array}{c}\text { Histology of } \\
\text { associated polyps }\end{array}$ & Treatment \\
\hline 1 & Nakamura et al. [5] & 1979 & 46 & $\mathrm{~F}$ & $\mathrm{~m}$ & Unknown & $\begin{array}{l}\text { Juvenile type } \\
+ \text { adenoma }\end{array}$ & Gastrectomy \\
\hline 2 & Yokoyama et al. [6] & 1983 & 70 & M & ss & $\mathrm{L}$ & Juvenile type & Gastrectomy \\
\hline 3 & Sagara et al. [7] & 1983 & 71 & M & $\mathrm{m}$ & $\mathrm{L}$ & Juvenile type & Gastrectomy \\
\hline 4 & Nisiki et al. [8] & 1984 & 58 & M & Unknown & Unknown & Juvenile type & Unknown \\
\hline 5 & Sugimura et al. [9] & 1984 & 51 & M & ss & Unknown & $\begin{array}{l}\text { Juvenile type } \\
+ \text { adenoma }\end{array}$ & Gastrectomy \\
\hline 6 & Isobe et al. [10] & 1985 & 72 & $\mathrm{~F}$ & $\mathrm{~m}$ & Unknown & Juvenile type & Gastrectomy \\
\hline 7 & Tsushita et al. [11] & 1985 & 61 & M & $\mathrm{sm}$ & Unknown & $\begin{array}{l}\text { Juvenile type } \\
+ \text { adenoma }\end{array}$ & Gastrectomy \\
\hline 8 & Uchida et al. [12] & 1986 & 60 & $\mathrm{~F}$ & $\mathrm{~m}$ & $\mathrm{~L}$ & $\begin{array}{l}\text { Juvenile type } \\
+ \text { adenoma }\end{array}$ & $\begin{array}{l}\text { Wide resection } \\
\text { of tumor }\end{array}$ \\
\hline 9 & Koido et al. [13] & 1986 & 78 & M & $\mathrm{s}$ & Unknown & Juvenile type & Total gastrectomy \\
\hline 10 & Yoshida et al. [14] & 1988 & 59 & M & $\mathrm{m}$ & M & Juvenile-type & Total gastrectomy \\
\hline 11 & Nouchi et al. [15] & 1990 & 68 & M & $\mathrm{m}$ & $\mathrm{U}$ & Juvenile type & Total gastrectomy \\
\hline 12 & Hasegawa et al. [16] & 1990 & 72 & M & $\mathrm{m}$ & $\mathrm{L}$ & $\begin{array}{l}\text { Juvenile type } \\
+ \text { adenoma }\end{array}$ & Total gastrectomy \\
\hline 13 & Ogawa et al. [17] & 1990 & 78 & $\mathrm{~F}$ & $\mathrm{~m}$ & Unknown & Juvenile type & Total gastrectomy \\
\hline 14 & Kaneko et al. [18] & 1991 & 69 & M & $\mathrm{sm}$ & $\mathrm{U}$ & Juvenile type & Gastrectomy \\
\hline 15 & Kumano et al. [19] & 1991 & 70 & M & ss & $\mathrm{L}$ & $\begin{array}{l}\text { Juvenile type } \\
+ \text { adenoma }\end{array}$ & Radiation therapy \\
\hline 16 & Yano et al. [20] & 1994 & 50 & M & SS & $\mathrm{L}$ & Juvenile type & Gastrectomy \\
\hline 17 & Yabushita et al. [21] & 1997 & 72 & M & ss & $\mathrm{U}$ & Juvenile type & Total gastrectomy \\
\hline 18 & Daidou et al. [22] & 1998 & 62 & M & $\mathrm{m}$ & M & Juvenile type & Total gastrectomy \\
\hline 19 & Present patient & 2000 & 52 & M & $\mathrm{mp}$ & $\mathrm{L}$ & Juvenile type & Total gastrectomy \\
\hline
\end{tabular}

m, Mucosa; sm, submucosa; mp, muscularis propria; ss, subserosa; L, lower portion of stomach; M, middle portion of stomach; U, upper portion of stomach

cancer is not correctly recognized, it is estimated to be $0.2 \%$, or 200 persons per 100000 population, with the mortality rate after surgery assumed to be $50 \%$. If this were the case, the $5.1 \%$ incidence of gastric cancer associated with Cronkhite-Canada syndrome suggests there may be a high-risk condition for stomach malignancy in patients with this syndrome, although the very large difference in population numbers prevents a precise correlation between these two cohorts. The histological types of the associated polyps in the 19 patients were: juvenile-type $(n=13)$ and adenoma coexisting with juvenile-type polyps $(n=6)$. Six reported patients with Cronkhite-Canada syndrome associated with gastric cancer showed adenoma and adenomatous changes around the cancer, suggesting the adenoma-carcinoma sequence in their carcinogenesis. However, in the present patient, only the cancer cells were stained with Ki-67 and p53, without any intermediate changes shown between the cancer nests and the surrounding mucosa, indicating that only the cancer cells had proliferative activity with mutated $\mathrm{p} 53$ protein. From these findings, it is likely that the etiology of gastric cancer in the present patient was coincidental. In the reported patients, the depth of invasion was histologically limited to the mucosa in 9 , to the submucosa in 2 , to the muscularis propria in 1 , to the subserosa in 6 , and was unknown in 1 patient.
Of the reported patients with Cronkhite-Canada syndrome associated with colorectal cancer, $41 \%$ (14/ $34)$ showed association with adenoma or adenomatous change. In some of the reported patients, adenomatous proliferation was seen in the epithelium at the tips of the juvenile-type polyps, and a clear transition to adenomatous proliferation and carcinogenic transformation was demonstrated. In addition, expression of mutant p53 protein was confirmed in parts of the adenomatous and carcinomatous areas, but not in the juvenile-type polyps [24]. In some colorectal cancers, the adenomacarcinoma sequence has been established as the carcinogenesis, and the reported adenomatous changes around gastric cancer nests in the patients with Cronkhite-Canada syndrome suggests that some gastric cancers in this syndrome may be related to the adenoma-carcinoma sequence, while other gastric cancers will have arisen coincidentally, as shown in the present patient. The etiology of gastric cancer in Cronkhite-Canada syndrome is controversial, regarding whether it is related to the adenoma-carcinoma sequence shown in colon cancer or whether it is coincidental (de novo). However, as all the reported patients with the Cronkhite-Canada syndrome associated with gastric cancer, including the present patient, had juvenile-type polyps, with only 6 of the 19 patients also showing adenoma, it is likely that the etiology 
of gastric cancer in the present patient may be coincidental.

Our patient with Cronkhite-Canada syndrome associated with gastric cancer was treated with total gastrectomy, as the remnant stomach may have retained malignant potential and the edematous mucosa could have led to anastomotic leakage because of the abnormal conditions. As one of the important reasons for Cronkhite-Canada syndrome having a poor prognosis is the malnutrition resulting from altered absorption in the gastrointestinal tract, it is also necessary to control protein loss. While a few patients have been successfully treated with enteral nutrition, steroids, and antiplasmin therapy [25-27], we, nevertheless, recommended surgery, as total gastrectomy also prevented protein loss [28]. General reasons for recommending total gastrectomy for patients with Cronkhite-Canada syndrome associated with gastric cancer are: (1) to obviate the malignant potential of the remnant stomach, (2) to reduce the high risk of anastomotic leakage caused by gastrointestinal edema, and (3) to prevent protein loss from the stomach. Reason (1) was appropriate in the present patient, as shown by the histological results, but this information was not obtained before or during the operation.

In conclusion, we suggest that patients with Cronkhite-Canada syndrome should be carefully screened, particularly for the stomach, colon, and rectum, so that the appropriate surgical therapy can be used to improve their survival outcome.

\section{References}

1. Cronkhite LW, Canada WJ. Generalized gastrointestinal polyposis. An unusual syndrome of polyposis, pigmentation, alopecia, and onychotrophia. N Engl J Med 1955;252:1011-5.

2. Japanese Gastric Cancer Association. Japanese classification of gastric carcinoma. 2nd English ed. Gastric Cancer 1998;1:10-24.

3. Goto A. Cronkhite-Canada syndrome associated with lesion predisposing to development of carcinoma (in Japanese). J Jpn Soc Cancer Ther 1994;29:1767-77.

4. Rubin M, Tuthill RJ, Rosato EF, Cohen IS. Cronkhite-Canada syndrome. Report of an unusual case. Gastroenterology 1980;79: 737-41.

5. Nakamura Y, Takagi S, Omoto R, Makino T, Yoshii T. A case of Cronkhite-Canada syndrome associated with cancer development of a gastric polyp (in Japanese). I To Cho (Stomach and Intestine) 1979;14:1217-22.

6. Yokoyama S, Yamashita H, Morichi A, Mochizuki Y, Nakamura $\mathrm{Y}$, Watanabe $\mathrm{H}$, et al. Cronkhite-Canada syndrome associated with adenosquamous carcinoma in gastric polyps, report of an autopsy case (in Japanese). I To Cho (Stomach and Intestine) 1983;18:981-5.

7. Sagara K, Fujiyama S, Kamuro Y, Tashiro A, Sato T. CronkhiteCanada syndrome associated with gastric cancer, report of a case. Gastroenterol Jpn 1983;18:260-6.

8. Nishiki M, Takasugi S, Kawano M, Okumichi T, Tamura T, Ezaki H. Cronkhite-Canada syndrome. Hiroshima J Med Sci 1984;33: 607-14.
9. Sugimura K, Fukasawa T, Suzuki T, Sugiura K, Funabashi W. A case of Cronkhite-Canada syndrome (in Japanese). Nichidai Ishi (J Nihon Univ Med Assoc) 1984;43:327.

10. Isobe S, Kurosawa K, Itoh Y, Hirata F, Adachi H, Ohta Y, et al. A case of Cronkhite-Canada syndrome associated with early gastic caner (in Japanese). Prog Digest Endosc 1985;26:243-6.

11. Tsushita K, Sugiura S, Orito E, Narita M, Ogino M, Kumada K. A case of gastric polyps peculiar to Cronkhite-Canada syndrome associated with gastric cancer (in Japanese). Jpn J Gastroeterol 1985;82:525.

12. Uchida Y, Kisu T, Mori H, Yamaoka K, Harada S, Mizoguchi T, et al. A case of Cronkhite-Canada syndrome with a giant villous tumor of the stomach-developing cancerous change, report of a case (in Japanese). I To Cho (Stomach and Intestine) 1986;21: 559-63.

13. Koido K, Natsui K, Oomura T, Nishizawa M, Tikama T, Horita A, et al. A case of Cronkhite-Canada syndrome with gastric cancer (in Japanese). Jpn J Gastroeterology 1986;83:565.

14. Yoshida H, Kawabe H, Akita M, Kitagawa Y, Ohta A, Hiramatsu $\mathrm{K}$, et al. A case of Cronkhite-Canada syndrome associated with early gastric cancer type 1 polyps (in Japanese). J Jpn Surg Assoc 1988;49:138.

15. Nouchi T, Zen S, Uchihara M, Sato T, Marumo F. A case of Cronkhite-Canada syndrome associated with early gastric cancer after improvement of polyposis due to steroid treatment (in Japanese). Gastroenterol Endosc 1990;32:2773.

16. Hasegawa H, Miyagi H, Kasanuki J, Suzuki Y, Kishi M, Yoshikawa N, et al. Carcinogenesis of Cronkhite-Canada syndrome (in Japanese). Gastroenterol Endosc 1990;32:2774.

17. Ogawa R, Tabui I, Kashiwagi M, Kaneda T, Tabata Y, Sekine T, et al. A case of Cronkhite-Canada syndrome associated with gastric cancer (in Japanese). J Jpn Surg Assoc 1990;51:2790.

18. Kaneko $\mathrm{Y}$, Kato $\mathrm{H}$, Tachimori $\mathrm{Y}$, Watanabe $\mathrm{H}$, Ushio $\mathrm{K}$, Yamaguchi $\mathrm{H}$, et al. Triple carcinomas in Cronkhite-Canada syndrome. Jpn J Clin Oncol 1991;21:194-202.

19. Kumano H, Kagawa N, Oshiro Y, Nishida K, Sadamoto K, Kamata T. A case of Cronkhite-Canada syndrom associated with gastric cancer (in Japanese). Hiroshima Med J 1991;44:637-42.

20. Yano $H$, Konishi $F$, Negishi $M$, Watanabe $H$, Terashima $H$, Watanabe $\mathrm{T}$, et al. A case of Cronkhite-Canada syndrome associated with gastric cancer (in Japanese). J Jpn Surg Assoc 1994;55:2978

21. Yabushita K, Konishi T, Egarashi M, Nishijima K, Murobayashi $\mathrm{O}$, Yoshida $\mathrm{T}$, et al. A case of Cronkhite-Canada syndrome associated with double cancer (colon and stomach) (in Japanese). Jpn J Gastroenterol Surg 1997;30:387.

22. Daidou H, Kawashima $Y$, Imose $M$, Itoh $H$, Nishimura $M$, Tsukada H, et al. A case of Cronkhite-Canada syndrome associated with minimum gastric cancer (in Japanese). Shiga Med J 1998;21:25-9.

23. Kakizoe T. Cancer Statistics in Japan (in Japanese). Tokyo: Foundation for Promotion of Cancer Research; 1997. pp. 42-3.

24. Mizukoshi E, Ooba S, Sakai M, Adachi K, Inagaki Y, Morimoto $\mathrm{H}$, et al. A case of Cronkhite-Canada syndrome with multiple adenomas and carcinoma of the rectum detected after improvement of polyposis due to steroid treatment. An analysis of expression of p53 protein in polyps (in Japanese). Jpn J Gastroenterol 1998;95:551-6.

25. Russell DM, Bhathal PS, St John DJ. Complete remission in Cronkhite Canada syndrome. Gastroenterology 1983;85:180-5.

26. Takahata J, Okubo K, Komeda T, Kono T, Fukui I. Generalized gastrointestinal polyposis associated with ectodermal changes and protein-losing enteropathy with a dramatic response to prednisolone. Digestion 1972;5:153-61.

27. Yamashita T, Miyazawa M, Suzuki T. Cronkhite Canada syndrome improved markedly with antiplasmin agent and steroid (in Japanese). Gastroenterol Endosc 1996;38:45-50.

28. Hanzawa M, Yoshikawa N, Tezuka T, Konishi K, Kaneko K, Akita Y, et al. Surgical treatment of Cronkhite-Canada syndrome. Dis Colon Rectum 1998;41:932-4. 